\title{
Supply projections for beef in Pakistan by the year 2030 AD
}

\author{
Khalid Mahmood Aujla ${ }^{1}$, Nadeem Sadiq ${ }^{2 *}$, Saadullah Laghari ${ }^{3}$ and \\ Muhammad Iqbal Jakhro ${ }^{2}$ \\ 1. Pakistan Agricultural Research Council, Islamabad-Pakistan \\ 2. Balochistan Agricultural Research \& Development Center, Quetta-Pakistan \\ 3. Department of Botany, University of Balochistan, Quetta-Pakistan \\ *Corresponding author's email: nadeemqta@yahoo.com \\ Citation \\ Khalid Mahmood Aujla, Nadeem Sadiq, Saadullah Laghari and Muhammad Iqbal Jakhro. Supply projections for \\ beef in Pakistan by the year 2030 AD. Pure and Applied Biology. Vol. 7, Issue 2, pp470-475. \\ http://dx.doi.org/10.19045/bspab.2018.70059
}

\begin{tabular}{llll}
\hline Received: 10/01/2018 & Revised: 28/03/2018 & Accepted: 31/03/2018 & Online First: 06/04/2018 \\
\hline \hline
\end{tabular}

\section{Abstract}

The supply projection for beef in Pakistan by the year 2030 AD has been made on the basis of time series data of the time period from 1980-81 to 2011-12. This study has been designed to estimate the beef meat projection supply chain in next decade in Pakistan. Both linear regression and polynomial price lag models are employed to analyze the effects of various factors on beef supply in the country. It is found that higher beef prices stimulate its production in the country. Availability of cattle and buffalo animal units for beef production also contributes positively and significantly to the production. Cattle and buffalo are good converters of fodder into products of highly nutritive value, thus increase in fodder prices has not affected beef production in the past and may not affect it to a large extent in future. However, a little impairment in the production technology for beef has been observed over time. It is projected that beef supply would be 2532 and 2535 thousand tones under linear and polynomial price lag models in the year 2030 AD, respectively. It is expected that beef production will grow at a lower rate of $2.0 \%$ per annum against past growth rate of $4.6 \%$ per annum from 1980-81 to 2011-12. Policy makers of the state may adopt policies to boost beef production in the country. This study draws the attention to set goals to achieve the expected target of beef meat in future to meet the needs of the country.

Keywords: Beef; Pakistan; Prices; Projections; Supply

\section{Introduction}

Livestock is an important sub-sector of agriculture. The sub-sector contributes $11.9 \%$ to national GDP. The livestock population is comprised of 39.7 million cattle, 34.6 million buffaloes, 66.6 million goats, 29.1 million sheep and one million camels [1]. Total supply of meat in the country in the year 2012-13 was 3497 thousand tonnes. National production of beef in the year 2012-13 was 1829 thousand tonnes. Thus, beef shares the most $(54.8 \%)$ in total meat supply in the country. While, shares of mutton and poultry meat in national meat production were 19.5 and 25.8 percent, respectively [2]. During last five years, production of beef has increased by 2.8 per annum, which is second highest growth rate in production of all meat types after poultry meat. Increase in population, urbanization, per capita income and export opportunities are fueling demand for meat and other 
livestock products in the country. On the other hand, increase in per unit animal productivity and a shift from subsistence to market oriented, and then to commercial livestock farming can boost economic growth and help improve food security situation in the country [1].

Official estimates about supply and demand of livestock products in the country made in the year 1999-2000 and 2004-05 depict a gloomy picture i.e. demand for beef and mutton have already surpassed production levels, and supply-demand gaps will get widened with the passage of time [3]. Thus, over time demand and supply issues of meat have become somewhat complex. Information about demand and supply of beef and other meat types is crucial for efficacious policy formulation for the development of the livestock sector. In this perspective, few researchers have analyzed supply of beef in Pakistan viz. [4, 5]. Study by Ahmad and Chaudhry was based on simple growth model; however, [5] used polynomial price lag model to estimate supply response functions of beef in the country. In the present study log linear regression model and polynomial price lag model have been employed to figure out impacts of various factors on the supply beef. The supply projections of beef towards year 2030 have also been made.

\section{Materials and methods}

Supply side analysis of beef is based on time series data for the time period 1980-81 to 2011-12 about production, prices, prices of fodder, amount of agricultural credit disbursed by Zari Taraqiati Bank Limited (ZTBL), buffalo and cattle animal units for beef production, and the stage of production technology. Prices as well as other monetary variables were converted at the prices of year 2000-01. Moreover, the projection of supply (production) requires knowledge of future values of exogenous variables. These variables are projected using their growth trends over the last thirty-two years (1980-81 to 2011-12). It is estimated that livestock animal units available for the beef production in the year 2011-12 were 14.9 million (8.7 million cattle and 6.2 million buffalo animal units), with per animal productivity of 120.8 $\mathrm{kg}$ per annum. It is projected that cattle and buffalo animal units available for beef production would be 20.4 million by the 2030. Thus, growth in livestock animal units for beef production would be 1.8 percent per annum. Growth in nominal and real prices of beef from 1980-81 to 2010-11 were 11.1 and 1.7 percent, respectively. Same growth rates in prices have been used for the beef supply projections. The linear regression and polynomial price lag models used for the study are given by equations 1 and 2 , respectively.

$$
\begin{aligned}
& \log S B_{t}=\beta_{\circ}+\beta_{1} \log P B_{t}++\beta_{2} \log P F+\beta_{3} \log A C+\beta_{4} \log C U+\beta_{5} \log B U+T+\mu_{t} \\
& (1) \\
& \log S B_{t}=\beta_{\circ}+\beta_{1} \log P B_{t}+\beta_{2} \log P B_{t-1}+\beta_{3} \log P B_{t-2}+\beta_{4} \log P F+\beta_{5} \log A C+ \\
& \beta_{6} \log B U+\beta_{7} \log C U+T+\mu_{t} \quad \text { (2) }
\end{aligned}
$$

Where

$\mathrm{SBt}$ is quantity of beef production

$\mathrm{PB}_{\mathrm{t}}$ is beef price of current period

$\mathrm{PB}_{\mathrm{t}-1}$ is one lag beef price

$\mathrm{PB}_{\mathrm{t}-2}$ is two lag beef price

$\mathrm{PF}$ is fodder prices
$\mathrm{AC}$ is amount of agricultural credit disbursed by ZTBL

CU is number of cattle animal units for beef production

$\mathrm{BU}$ is number of buffalo animal units for beef production 
$\mathrm{T}$ is the time, which is a proxy for technological change and

$\beta i$ 's are the coefficient of the variables.

$\mu_{t}$ is error term, which may arise due to aggregate effect of variables not included in the model.

The supply projections for the beef are obtained by using the expression given by equation 3

$S_{t}=S_{0} * N_{t}\left(1+P_{g} * P_{s}\right)(3)$

Where,

$\mathrm{S}$ is supply/ production of beef in year $\mathrm{t}$

$\mathrm{S}_{0}$ is the beef production per animal unit in the base year (2011-12),

$\mathrm{P}_{\mathrm{g}}$ is growth in nominal prices,

$\mathrm{P}_{\mathrm{s}}$ is price elasticity of supply for beef;

$\mathrm{N}_{\mathrm{t}}$ is projected animal units (cattle + buffalo) for beef production in year $t$.

Results and discussion

\section{Unit Root Test (Augmented Dickey-Fuller} Test: ADF)

The results of unit root test are given in Table 1. The variable of beef production (SB) is non-stationary at level without both intercept and trend terms, but becomes stationary at first difference. The variables of beef price (PB) is stationary at level along with intercept and trend terms. The variable of buffalo animal units for beef production (BU) is nonstationary at level along with intercept and trend terms, however becomes stationary at first difference. The variables of fodder price (PF) and agricultural credit disbursed by ZTBL (AC) are non- stationary at level along with intercept, but become stationary at first difference. The variable of cattle animal units for beef production (CU) is non-stationary at level without both intercept and trend terms, but becomes stationary by taking first difference.

Table 1. Unit Root Test (Augmented Dickey-Fuller Test: ADF)

\begin{tabular}{|c|c|c|c|c|}
\hline Variables & $\begin{array}{c}\text { Intercept / Intercept } \\
\text { and Trend }\end{array}$ & Level & Ist-difference & $\begin{array}{c}\text { Order of } \\
\text { Integration }\end{array}$ \\
\hline SB & None & 4.354 & $-3.535^{* * *}$ & I (1) \\
\hline PB & Intercept \& Trend & $-3.677 * *$ & - & I (0) \\
\hline PF & Intercept & -2.827 & $-6.197 * * *$ & I (1) \\
\hline AC & Intercept & -2.204 & $-4.577^{* * *}$ & $\mathrm{I}(1)$ \\
\hline CU & None & 0.347 & $-6.346 * * *$ & I (1) \\
\hline BU & Intercept \& Trend & -2.400 & $-5.354^{* * *}$ & I (1) \\
\hline
\end{tabular}

The estimated coefficients of linear regression model are presented in the Table 2. Most of the variables have expected signs. The coefficient of price for beef is positive and statistically significant, implying that higher prices stimulate beef production in the country. Cattle and buffalo animal units also contribute positively and significantly to beef production. The coefficient of Agricultural Credit disbursed by Zari Taraqiati Bank Limited (ZTBL) also has a positive coefficient but is statistically insignificant. Fodder price elasticity for beef production is positive and statistically significant, indicating that rise in fodder prices has not resulted in to a decrease in beef production in the past and may not affect it gravely in future. This means that cattle and buffalo are good converters of fodder into products of highly nutritive value. The negative sign of time variable indicates bit impairment in the production technology for beef over time. 
Table 2. Estimates of the supply response model (Linear regression)

\begin{tabular}{|c|c|c|c|c|}
\hline Variables & Coefficient & Std. Error & t-Statistic & Prob. \\
\hline Constant** & -0.400 & 0.146 & -2.737 & 0.012 \\
\hline Beef Price*** & 0.248 & 0.086 & 2.876 & 0.008 \\
\hline Fodder Price*** & 0.200 & 0.065 & 3.083 & 0.005 \\
\hline Agricultural Credit & 0.042 & 0.037 & 1.143 & 0.265 \\
\hline Cattle Animal Units*** & 0.733 & 0.182 & 4.023 & 0.001 \\
\hline Buffalo Animal Units** & 0.891 & 0.342 & 2.606 & 0.016 \\
\hline Time $^{* * *}$ & -0.002 & 0.001 & -3.064 & 0.005 \\
\hline $\mathrm{R}^{2}$ & 0.505 & Mean dependent var & 0.020 \\
\hline Adjusted R $^{2}$ & 0.381 & S.D. dependent var & 0.021 \\
\hline S.E. of regression & 0.017 & Akaike info & & -5.151 \\
\hline Sum squared resid & 0.007 & Schiterion & & -4.827 \\
\hline Log likelihood & 86.841 & F-statistic & & 4.074 \\
\hline Durbin-Watson stat & 2.000 & Prob (F-statistic) & 0.006 \\
\hline
\end{tabular}

Note: $* * *$ and ${ }^{* *}$ are significant at 1 and 5 percent levels, respectively

The polynomial price lag model estimates are presented in Table 3. Coefficients of beef price of the current period and with one lag value have expected positive signs. While coefficient of beef price with two lags has a negative sign. However, coefficients of beef price in the polynomial price lag model are statistically insignificant. According to results of polynomial price lag model, increase in both buffalo and cattle animal units for beef production would increase its supply in the country. All other variables of the polynomial price lag model have similar interpretations as given in the linear regression model.

Table 3. Estimates of the supply response model (Polynomial price lag model)

\begin{tabular}{|c|c|c|c|c|}
\hline Variables & Coefficient & Std. Error & t-Statistic & Prob. \\
\hline Constant** & -0.427 & 0.200 & -2.140 & 0.044 \\
\hline Beef Price & 0.245 & 0.178 & 1.376 & 0.183 \\
\hline Beef Price $t-1$ & 0.094 & 0.260 & 0.363 & 0.720 \\
\hline Beef Price $t-2$ & -0.079 & 0.178 & -0.445 & 0.661 \\
\hline Fodder Price**** & 0.285 & 0.079 & 3.621 & 0.002 \\
\hline Agricultural Credit & 0.029 & 0.039 & 0.754 & 0.459 \\
\hline Cattle Animal Units*** & 0.903 & 0.206 & 4.390 & 0.000 \\
\hline Buffalo Animal Units*** & 1.350 & 0.420 & 3.213 & 0.004 \\
\hline Time** & -0.002 & 0.001 & -2.601 & 0.017 \\
\hline $\mathrm{R}^{2}$ & 0.575 & \multicolumn{2}{|c|}{ Mean dependent var } & 0.020 \\
\hline Adjusted $\mathrm{R}^{2}$ & 0.412 & \multicolumn{2}{|c|}{ S.D. dependent var } & 0.022 \\
\hline S.E. of regression & 0.017 & \multicolumn{2}{|c|}{ Akaike info criterion } & -5.125 \\
\hline Sum squared resid & 0.006 & \multicolumn{2}{|c|}{ Schwarz criterion } & -4.704 \\
\hline Log likelihood & 85.868 & \multicolumn{2}{|c|}{ F-statistic } & 3.545 \\
\hline Durbin-Watson stat & 2.061 & \multicolumn{2}{|c|}{ Prob (F-statistic) } & 0.009 \\
\hline
\end{tabular}

Note: $* * * * *$ and $*$ are significant at 1,5 and 10 percent levels, respectively 
The price elasticity of beef obtained through linear regression is 0.248 . Elasticity of beef obtained through polynomial price lag model (by taking sum of elasticity estimates of current year, previous year and year before previous year) is 0.260 . The production of beef in the year 2011-12 was 1769 thousand tonnes. Similarly, the per capita beef production is forecasted to be $25.2 \mathrm{~kg} / \mathrm{annum}$ in Pakistan, $60 \mathrm{~kg}$ in China, $6 \mathrm{~kg}$ in India and $87 \mathrm{~kg}$ in Developing World in 2020 [6]. The supply projections for the year 2030 with both linear and polynomial price lag models are 2532 and 2535 thousand tonnes, respectively. Thus, beef production is expected to grow at annual compound rate of 2.0 percent. Beef production in the country has grown by 4.6 percent per annum from 1980-81 to 2011-12, respectively. Thus, a slowdown in beef production in the country is expected in near future. The reason may be decreasing capacity of the livestock farmers to support large cattle herds due to division of land. Majority of the farms in the country $(64 \%)$ are already smaller than 2 hectare. Mean herd size in the country is 2-3 cattle/buffalo and 5-6 sheep/goats per family [7]. Forty three percent households keep 1-2 cattle/buffalo and twenty seven percent have 3-4 cattle/buffalo, and remaining 30\% keep 5 and more cattle/buffalo in the country [8]. Consumer preferences for meat are also changing rapidly. Consumers prefer more western diets [9], mostly containing white meat. Production of white meat is also increasing with adoption of controlled house broiler farms and fish farming in the country. Presently number of environmental control houses for poultry meat production in Pakistan are 2500, out of which 75 percent (1875) are in Punjab and reaming 25 percent (625) are in other provinces [10].

\section{Conclusion and recommendations}

Beef shares the most in national meet supply. The demand of beef has already surpassed it supply. Moreover, growth in its production is decreasing overtime. Most of the cattle/buffalo farms in the country are subsistence. Thus, a shift from subsistence to market oriented and commercial farms is required to boost beef production in the country. Along with this, encouragement of smallholder livestock production should also be sought. This is also imperative to control increasing beef prices and to improve its intake by the people. Other important causes of lowering beef production are poor feeding and outdated livestock husbandry practices [11]. Thus, there is a dire need to teach farmers about better animal husbandry practices and to increase their capacity to ameliorate animal feeding. [12] stated that education status of the farmers, herd size, information utilization pattern and information seeking behaviour are the factor significantly correlated with adoption of scientific livestock farming. These farmers' characteristics should also be considered, while designing educational programs for them. Policy reforms for cattle/buffalo fattening may include, improved access to institutional credit, production inputs and marketing facilities for the farmers.

\section{Authors' contributions}

Conceived and designed the experiments: KM Aujla, Performed the experiments: KM Aujla, Analyzed the data: N Sadiq, Contributed reagents/ materials/ analysis tools: KM Aujla, N Sadiq, S Laghari \& MI Jakhro, Wrote the paper: KM Aujla \& N Sadiq.

\section{References}

1. GOP (2014). Pakistan Economic Survey 2013-14. Economic Advisor's Wing, Finance Division, Government of Pakistan, Islamabad.

2. GOP (2013). Pakistan Economic Survey 2012-13. Economic Advisor's Wing, Finance Division, Government of Pakistan, Islamabad.

3. GOP (2006). Pre-feasibility study for cattle farming and meat processing plant. 
Employment and Research Section, Planning and Development Division, Government of Pakistan, Islamabad.

4. Ahmad M \& Chaudhry MA (1993). Demand and supply projections for major livestock products for the year 2000 and new policy options. Pak J Agric Sci 30(2): 139-144.

5. Akmal M (1994). The production and consumption of livestock food in Pakistan: A look into the Future. The Pak Development Review 33(1): 19-39.

6. Nouman S (2014). Modeling and forecasting of beef, mutton, poultry meat and total meat production of Pakistan for year 2020 by using time series arima models. European Scientific J ESJ 10(10).

7. GOP (2010). Pakistan Agricultural Census Report 2010. Agricultural Census Organization, statistic Division Govt. of Pakistan Islamabad.

8. GOP (2006a). Pakistan Livestock Census 2006. Agricultural Census Organization, Government of Pakistan, Lahore.
9. Halweil B (2008). Meat production continues to rise. Vital Signs Online. (Available at www.worldwatch.org).

10. NBP (2013). Poultry farming controlled environment. Agriculture Feasibility Reports. R \& D and Training Wing. Agriculture Finance Group, National Bank of Pakistan Head office, Lahore. (Available on line at http://www.nbp.com.pk/Agriculture/)

11. Mansoor K, Chaudhry M, Muhammad S, Ashraf I \& Ghafoor U (2012). Farmer's perceptions of livestock production practices introduced by Punjab Rural Support Programme (PRSP). Pak J Agri Sci 49(2): 233-235.

12. Jaisridhar P, Sankhala G, Kadian KS, Kumar S \& Sangeetha S (2013). Factors determining adoption of scientific dairy farming with special reference to farmers call centre of Tamil Nadu. Pak J Agri Sci 50(4): 549-553. 